\title{
Studies on E. Coli Isolated From Newly Weaned Rabbits in Ismailia Governorate
}

\author{
Ahmed, A. Khafagy, *Mohamed, K. Moursi, *Doaa, H. Ahmed \\ (Dept. of Microbiology - Fac. Of Vet. Med. Suez Canal University) \\ *(National lab. For vet. Quality control on poultry production - Ismailia)
}

\begin{abstract}
:
This study was planned to gain more about E. coli causing diarrhea in newly weaned rabbits in Ismailia governorate. A total of (192) rectal swab was collected from newly weaned dirrhoiec rabbits at different seasonal period extended from (April 2014 -March 2015) to examine the presence of E. coli. These isolates were further characterized by biochemical tests and polymerase chain reaction. E. coli was isolated in 84 of the 192 samples (43.75\%). Seasonal prevalence of Escherichia coli infection revealed that the highest incidence occurred in summer season $29 / 84(65.9 \%)$. Followed by spring $21 / 84(40.4 \%)$, then in winter $15 / 84(32.6 \%)$, and finally in autumn $19 / 84(38 \%)$. The isolated E. coli strain were found to belong to $\mathrm{O}$ stereotypes in order of frequency O158, O128, O125, O27, O18, O20, O148 and Untypable $(20 \%, 13.33 \%, 13.3313 .33 \%, 6.67 \%, 6.67 \%$, $6.67 \%$, and $20 \%$ isolates respectively). Based on PCR, All examined $E$. coli were positive100 \%( 7/7) for eae virulence gene, while $87.8 \%(6 / 7)$ of the tested E. coli isolates were positive to tsh gene. It was concluded that Combination of genotypic with phenotypic analysis of $E$. coli isolates is more valuable as an epidemiological tool for differentiation and identification of the isolates than one test alone.
\end{abstract}

\section{Introduction:}

Rabbits are raised for a variety of purposes, including their use in laboratory, and fur, which constitute a valuable by-product, meat, besides being efficient converters of vegetable protein into high quality animal protein. The production of rabbit meat on an industrial scale has been very slow to develop due to excessive mortality among growing rabbit which hinder mass production (Okerman, 1999).
Escherichia coli bacterium is a member of the family Enterobacteriacae facultative anaerobic, gram-negative short rods and considered a common inhabitant of the gut of the wormblooded animals, including man (WHO, 1996). On eosin methylene blue (EMB) agar media, E. coli, showing characteristic dark colonies with a metallic sheen. In addition, E. coli can ferment most sugarswith 
production of acid and gas

(Rahman et al, 2004).

E. coli infection is the primary causative agent in most outbreaks of diarrhea in newly weaned rabbits (Peeters et al, 1984 and Percy et al, 1993), Several strains of varying virulence cause diarrhea in rabbits belong to different serotypes (Okerman, 1999). the enterotoxogenic E. coli (ETEC) is leading to infectious diarrhea worldwide (Wolf, 1997), while all E. coli strains cause diarrhea in rabbits is the classical enteropathogenic $\quad E$ coli (EPEC), which typically do not produce known enterotoxins or Shiga toxins but damage the intestinal epithelial cells by effacing the microvilli and attaching intimately to the cell membrane. This leads to the characteristic "attaching and effacing" (AE) lesion and diarrhea. The adherence of bacteria to the enterocytes is mediated by intimin, an outer membrane protein encoded by eaeA that mediates close attachment of enteropathogenic bacteria to apical surfaces of epithelial cells, is required for formation of the attaching-effacing lesions and for full pathogenesis of the bacteria (Frankel et al, 1998 and Nataro and Kaper, 1998).

Tsh gene, is another adhesionrelated factor. The $t s h$ gene, encoding a temperature-sensitive hemagglutinin, was isolated and characterized by (Provence and Curtiss, 1994) and may act as an adhesin, particularly in the initial stages of bacterial colonization. The Tsh autotransporter seems to be one of the factors associated with induce fluid accumulation in the rabbit gut (Maluta et al ,2014).

In Egypt there is a little literatures on newly weaned rabbit diarrhea causes by E.coli. So, this study takes the problem of E.coli infection from a microbiological point of view. This work is planned to investigate the microbial studies on newly weaned rabbits causing diarrhea in Ismailia governorate.This is achieved by Isolation of $E$. coli from weaned rabbits, Biochemical and Serological identification of isolated strains as well as detection of some virulence genes.

\section{Material and methods}

\section{Sample:}

A total of 192 rectal swabs were obtained from live newly weaned (28 - 40 days old) Newzeland white rabbits from 4 farms from different localities in Ismailia province, which suffered from diarrhea, high morbidity and mortality rates during extended periods of seasons (summer, winter, autumn, spring). Samples were directly transferred to the bacteriological laboratory in Ismailia for examination without delay.

\section{Bacteriological examination:}

A- Isolation and biochemical identification of $E$. coli:

Collected samples were enriched first on buffered peptone broth 
incubated aerobically at $37 \mathrm{C}^{\circ}$ for 24 hours, then a loopful from each sample was inoculated separately onto MacConkey agar and Eosin methylene blue agar. The inoculated plates were aerobically incubated at $37 \mathrm{C}^{\circ}$ for $24 \mathrm{~h}$. Suspected colonies were subjected to morphological and biochemical identification according to Cruickshank et al (1975 and 1982). B-Serological identification:

The preliminarily identified isolates biochemically as E. coli was subjected to serological identification according to Quinn et al (1994 and 2002) for determination of $(\mathrm{O})$ antigen using slide agglutination test.

C- molecular characterization and detection of virulence genes in $E$. coli isolates using PCR:

1-extraction of DNA according to QIAamp DNA mini kit instructions.

2-preparation of PCR master mix according to Emerald Amp GT PCR master mix (Takara).

3-Cycling conditions of the primers during cPCR.

4-DNA molecular weight marker.

Agarose gel electrophoresis (Sambrook et al, 1989).

Table (1): Cycling conditions of the different primers during $c P C R$.

\begin{tabular}{|c|c|c|c|c|c|c|c|}
\hline $\begin{array}{c}\text { Target } \\
\text { Gene }\end{array}$ & $\begin{array}{c}\text { Primary } \\
\text { denaturation }\end{array}$ & $\begin{array}{c}\text { Secondary } \\
\text { denaturation }\end{array}$ & Annealing & Extension & $\begin{array}{c}\text { No. of } \\
\text { cycles }\end{array}$ & $\begin{array}{c}\text { Final } \\
\text { extension }\end{array}$ & references \\
\hline eae $\boldsymbol{A}$ & $\begin{array}{c}94^{\circ} \mathrm{C} \\
5 \mathrm{~min} .\end{array}$ & $\begin{array}{c}94^{\circ} \mathrm{C} \\
30 \mathrm{sec} .\end{array}$ & $\begin{array}{c}51^{\circ} \mathrm{C} \\
30 \mathrm{sec} .\end{array}$ & $\begin{array}{c}72^{\circ} \mathrm{C} \\
30 \mathrm{sec} .\end{array}$ & 35 & $\begin{array}{c}72^{\circ} \mathrm{C} \\
7 \mathrm{~min} .\end{array}$ & $\begin{array}{c}\text { Bisi- } \\
\text { Johnson } \\
\text { et al. } \\
\mathbf{2 0 1 1}\end{array}$ \\
\hline $\boldsymbol{T} \boldsymbol{s} \boldsymbol{h}$ & $\begin{array}{c}94^{\circ} \mathrm{C} \\
10 \mathrm{~min} .\end{array}$ & $\begin{array}{c}94^{\circ} \mathrm{C} \\
45 \mathrm{sec} .\end{array}$ & $\begin{array}{c}54^{\circ} \mathrm{C} \\
45 \mathrm{sec} .\end{array}$ & $\begin{array}{c}72^{\circ} \mathrm{C} \\
45 \mathrm{sec} .\end{array}$ & 35 & $72^{\circ} \mathrm{C}$ & $\begin{array}{c}\text { Delicato } \\
\text { et al. } \\
\mathbf{2 0 0 3}\end{array}$ \\
\hline
\end{tabular}

\section{Results}

1-Results of isolation and biochemical identification of $E$. coli:

The morphological characters of $E$. coli revealed that, all isolates were Gram negative, medium sized bacilli to coccobacilli, non sporulated and arranged single, in pairs or in short chains. Appeared as smooth, shinny, strong lactose fermenting colonies on MacConkey's agar and characteristic greenish metallic sheen on EMB as shown in fig (1). Biochemically, all E. coli suspected isolates were lactose fermenting colonies and positive Indole, methyle red and catalase. Meanwhile, all isolates were negative oxidase, urea hydrolysis, citrate utilization, voges-proskauer and not produced $\mathrm{H} 2 \mathrm{~S}$ (table: 2).

The allover incidence of E.coli isolation from a rabbit with diarrhea as shown in table (3) was $43.75 \%$ (84/192). Escherichia coli 
wasrecovered with high rate $(66.67 \%)$ from farm (4) in El Tal El-kbeer, followed by Farm (1) Faculty of Veterinary Medicine $(39.28 \%)$ and Farm (2) faculty of agriculture $(36.36 \%)$. While, the lowest rate was from Farm (3) Abo Swear (36\%). Typical Escherichia coli lactose fermenting colonies on MacConkey agar, metallic green sheen-like colonies on Eosin Methylene Blue .Seasonal prevalence of Escherichia coli infection in weaned rabbits revealed that the highest incidence occurred in summer season 29/84 (65.9\%). Followed by spring 21/84(40.4\%), then in autumn $19 / 84(38 \%)$, and finally in winter $15 / 84(32.6 \%)$ as shown in table (4).

\section{2-Results of serological} identification of isolated $E$. coli:
Serotyping was applied to isolated E. coli (table 5), the isolated E. coli strain, from diarrhoeic rabbit were found to belong to $\mathrm{O}$ stereotypes in order of frequency O158, O128, O125, O27, O18, O20, O148 and Untypable $(20 \%, \quad 13.33 \%, 13.33$ $13.33 \%, 6.67 \%, 6.67 \%, 6.67 \%$, and $20 \%$ isolates respectively).

3-Results of molecular characterization and detection of $E$. coli virulence genes:

As shown in table (6) and fig. (2) PCR assay was carried out for all detected serotypes (O158, O128, $\mathrm{O} 125, \mathrm{O} 20, \mathrm{O} 27, \mathrm{O} 18$ and $\mathrm{O} 148)$ to detect 2 virulence genes (eae and tsh). It was found that $100 \%(7 / 7)$ of tested E. coli isolates carry eae virulence gene, while $87.8 \%(6 / 7)$ of the tested $E$. coli isolates were positive to tsh gene.

Table (2): Results of biochemical reaction of E.coli isolates:

\begin{tabular}{|c|c|}
\hline Test & Reaction \\
\hline Oxidase & - \\
Catalase & + \\
Motility & + \\
Methyl red & + \\
Voges Proskauer & - \\
Indole & + \\
Simmon's citrate & - \\
Urea & - \\
Hydrogen sulphide & - \\
Glucose & + \\
Lactose & + \\
Mannitol & + \\
Sorbitol & + \\
Sucrose & $\mathrm{V}$ \\
TSI & Y/Y with gas production \\
\hline
\end{tabular}

V=variable $\quad-=$ negative and $+=$ positive 
Table (3): The prevalence of Escherichia coli isolated from diarrheic rabbits from different localities.

\begin{tabular}{|c|c|c|c|}
\hline Farm & $\begin{array}{c}\text { Number } \\
\text { samples }\end{array}$ & $\begin{array}{c}\text { Number of biochemically } \\
\text { positive isolates }\end{array}$ & Percentage \\
\hline $\mathbf{1}$ & 56 & 22 & $39.28 \%$ \\
\hline $\mathbf{2}$ & 44 & 16 & $36.36 \%$ \\
\hline $\mathbf{3}$ & 50 & 18 & $36 \%$ \\
\hline $\mathbf{4}$ & 42 & 28 & $66.67 \%$ \\
\hline Total & 192 & 84 & $43.75 \%$ \\
\hline
\end{tabular}

Table (4): Seasonal prevalence of E. coli recovered from weaned rabbits.

\begin{tabular}{|c|c|c|c|}
\hline \multirow{2}{*}{ Season } & \multirow{2}{*}{ No. of examined samples } & \multicolumn{2}{|c|}{ Incidence } \\
\cline { 3 - 4 } & 50 & No. & \% \\
\hline Autumn & 46 & 19 & 38 \\
\hline Winter & 52 & 15 & 32.6 \\
\hline Spring & 44 & 21 & 40.4 \\
\hline Summer & 192 & 29 & 65.9 \\
\hline & & 84 & $\%$ \\
\hline
\end{tabular}

Table (5): Escherichia coli serovars recovered from diarrhoeic rabbits.

\begin{tabular}{|c|c|c|}
\hline Serotype & Number & Percentage* $^{*}$ \\
\hline O158 & 3 & 20 \\
O128 & 2 & 13.33 \\
O125 & 2 & 13.33 \\
O27 & 2 & 13.33 \\
O18 & 1 & 6.67 \\
O20 & 1 & 6.67 \\
O148 & 1 & 6.67 \\
Untypable & 3 & 20 \\
\hline Total & 15 & 100 \\
\hline
\end{tabular}

Table (6): Prevalence of virulence genes (eaeA, tsh,) detected by $c P C R$ among Isolated diarrhoegenic E.coli strains

\begin{tabular}{|c|c|c|}
\hline Virulence & E.coli isolates & Percentage \\
\hline eae A & $7 / 7$ & $100 \%$ \\
\hline Tsh & $6 / 7$ & $87.8 \%$ \\
\hline
\end{tabular}



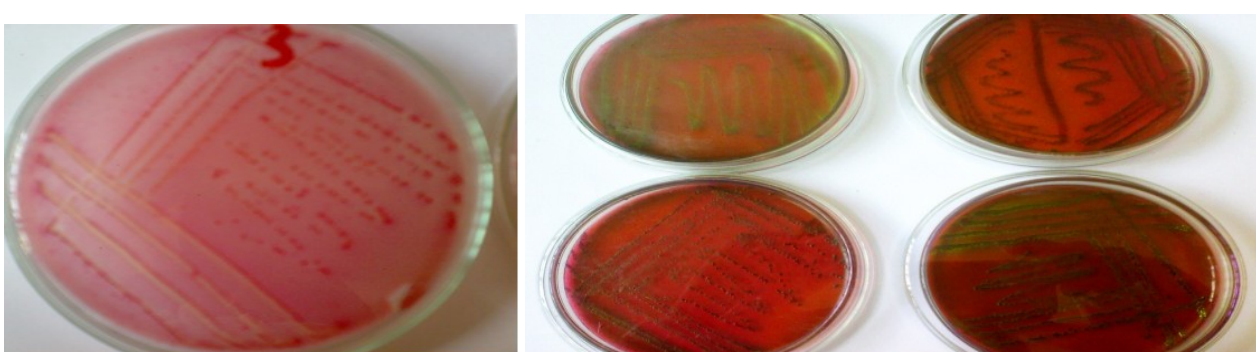

Fig. (1): E. coli colonies on Mackonkey agar and EMB.

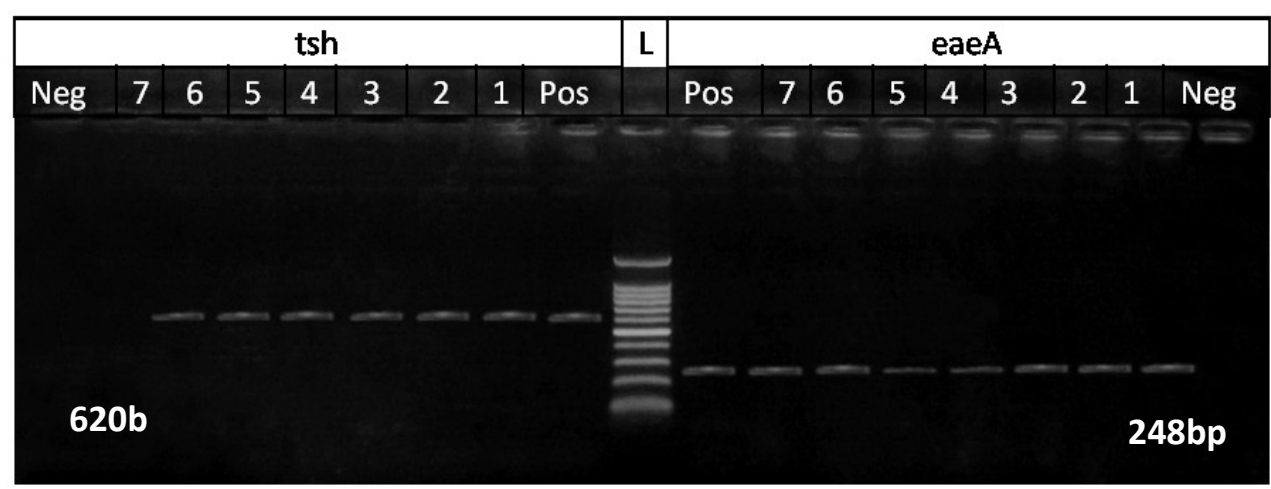

Fig. (2): Agarose gel electrophoresis of amplified tsh PCR product (620bp) and amplified eaeA PCR product (248bp).

\section{Discussion}

Diarrhea and mortality resulting from infections with Enteropathogenic Escherichia coli (EPEC) are of major economic importance in the rabbit meat industry (Stakenborg et al, 2006). There are many diseases facing a young age of rabbits (pre and post weaning age). Enteritis is one of the major problems facing rabbitries in Egypt, causing high mortalities.

In the present study, we have been trying to throw the light on the role of $E$. coli which incriminated as a main cause of diarrhea in newly weaned rabbits.

One hundred and ninety two rectal swabs from diarrhoeic rabbits were subjected for isolation and identification of $E$. coli The result indicated that, 48 of suspected isolates were biochemically identified as E. coli or by other meaning, the allover incidence of $E$. coli isolation from a rabbit with diarrhea was $43.75 \%$ (84/192)(table:3). This result is less than that isolated by Morsy et al (2002) as they recovered E. coli from newly weaned rabbit by $80 \%$ from examined samples (60/90) in Ismailia. While Alton et al (2012) isolated $E$. coli from fecal culture of all examined rabbit with diarrhea. As well as Shahin et al (2011) 
isolated E. coli by $65.7 \%$ from rabbit with Mucoid Enteropathy (38/45) in Dakhlia Governorate.

Concerning, seasonal prevalence of Escherichia coli infection in weaned rabbits (table:4). The result showed that, summer season was found to be the most important season that influenced the post weaning diarrhea in rabbits. (65.9\%) during summer compared to $38 \%, 32.6 \%, \quad 40.4 \%$ during autumn, winter and spring seasons respectively. This result higher than Habeeb et al (1997) who showed that, the mortality rate was found to be $18 \%$ in summer season, while no mortality was recorded during winter season. While, Shehata et al (1998) recorded $18.52 \%$ mortality rate during summer season compared to $(3.70,7.41$ and $7.41 \%)$ during spring, autumn and winter seasons, respectively. Also, Ghosh et al (2008) declared that, winter season (November - March) was the most favourable season for kindling,whereas summer season (April-June) proved to be an unfavorable season for both productive and reproductive efficiency in rabbits.

Concerning, serological serotyping in the current study (table:5), 15 E.coli isolates recovered from weaned rabbits were distributed among 7 different $\mathrm{O}$ serotype groups besides untypable ones. The most prevalent serogroup were O158 (20\%) followed by O128, O125, O27and untypable (13.33\%) and O20, O18, O148 (6.67\%). Such result coincided with serogroups recovered from newly weaned diarrhoeic rabbit by several authors.where, Percy et al (1993) and Blanco et al (1994) isolated 0128, and untyped from newly weaned diarrhoeic rabbits. Leroy et al (1994) and Azza (1998) recovered 0128. Saad (1994) isolated E. coli $\mathrm{O} 125$ from weaned rabbits. Aisha and Youseif (1999) isolated 0128, O125, O158 and untyped strains. Alshimaa (2007) isolated E. coli serogroup O125 from rabbits with enteritis. Shahin et al (2011) isolated E.coli serogroup $\mathrm{O} 158$ from diarrhoiec rabbits Zienab (2000) recovered 0128 and untyped from newly weaned diarrhoeic rabbits. Morsy et al (2002) found that, Serotypes associated with diarrhoea in newly weaned rabbits in Ismailia were (O119, O103, O55, O153, O128) and untypable ones with variable percentages. Blanco et al (1997) and Marches et al (2000) found that, most common serotypes among E. coli strains associated with diarrhoea in rabbit in order of frequency were $(0103,049,026$, 0128, 092) on the other hand Leroy et al (1994) recorded the isolation of 6 nonpathogenic diarrhoeic $E$. coli belonged to (0128) and (0132). Results of PCR analysis(table:6) showed that (7/7) $100 \%$ of tested $E$. coli strains isolated from weaned rabbits with diarrhea carried (eaeA) virulence gene. This result agreed with Penteado et al (2002) and 
Blanco et al (2005). While, Alton et al. (2012) reported that, fecal culture examination of 20 rabbits yielded $48 \mathrm{E}$. coli isolates, $83 \%$ of which were eae positive. Alexis and James (2003) found that, (25\%) of 28 rabbits were positive for eae gene.

Based on the obtained molecular results, it explained the severity of clinical signs and morbidity and mortality of weaned rabbits where, The intimin (eaeA gene) considered as indicator of attaching and effacing pathogenicity factor. It was present in $100 \%$ of tested isolates. So, this gene is clearly associated with diarrhoeagenic $E$. coli which increased the severity and duration of diarrhoea as well as mortality and the host inflammatory response (Mashood et al, 2009).

Concerning, tsh gene, is another adhesion- related factor. The temperature-sensitive

hemagglutinin was first identified in avian-pathogenic Escherichia coli (APEC) strain O78:K80 strain $\mathrm{x} 7122$ (Provence and Curtiss, 1994).

The result of this study proved that E. coli isolates for the presence of temperature sensitive hemagglutinin gene $(t s h)$ revealed that $(6 / 7) 85.7 \%$ of the examined E.coli strains from weaned rabbits with diarrhea bearing the virulence gene $(t s h)$. Which go in parallel with Hanchun et al (2004) who detected tsh gene in $93 \%$ of E. coli isolates from diseased animals with diarrhoea .While, this result not matched with Abhirrosh and Asit (2013) who did not detect tsh gene in the tested E. coli strains isolated from diarreic rabbits. Meanwhile, Maluta et al (2014) suggested that, EPEC might induce fluid accumulation in the rabbit gut. The tsh autotransporter seems to be one of the factors associated with this phenotype. Also Hagedorn et al (2011) reported that ,although $t s h$ gene associated with the bird, it was also found in $46 \%$ of E.coli isolated from a dog with diarrhea, which leading the authors to propose that, this gene would be a better source tracking marker from faeces of other animals.

\section{References:}

Abhirrosh, C. and Asit, M. (2013): Prevalence of Diarrhea associated virulence genes and genetic diversity in Escherichia coli isolated from fecal material of various animal hosts. Applied and environmental.

Microbial. 79(23):7371-7380.

Aisha, R.A. and Yousief, H.M.Z. (1999): Escherichia coli isolated from chickens and rabbits with special reference to their pathogenicity. J. Egypt Vet. Med. Ass. 59 (1) 45-59.

Alexis, G. and James, G. F. (2003): The Rabbit as a New Reservoir Host of Enterohemorrhagic Escherichia coli. Emerging Infectious Diseases. Applied and environmental. Microbial. 79(1):411-414.
Alshimaa,
A.M.
(2007): 
Bacteriological studies on enteric microorganisms in rabbits. Master degree in bacteriology. Vet. Med. Beni-suif Univ. Alton G. S., Ellen M. B., Nicola M. A.; Parry, C. M.; Madden, A.;García, P. B.;Morgan, K. M. ;Astrofsky and James G. F. (2012): Enzootic Enteropathogenic Escherichia coli Infection in Laboratory Rabbits. Journal of Clinical Microbiology 50 (7):2353-2358.

Azza, A.H. (1998): Properties of $E$. coli strains isolated from septicemic rabbits and chickens. PH.D thesis (Microbiology), Fac. of Vet. Med. Suez Canal University.

Bisi-Johnson, M. A.; Chikwelu, L. O.; Sandeep, D.V.; Kamaldeen, A.B. and Toshio, H. (2011): Molecular basis of virulence in clinical isolates of Escherichia coli and Salmonella species from a tertiary hospital in the Eastern Cape, South Africa. Gut Pathogens, 3:9.

Blanco, J.E., Blanco, M., Blanco, J., Rioja, L. and Ducha, J. (1994): Serotypes, toxins and antibiotic resistance of Escherichia coli strains isolated from diarrhoeic and healthy rabbits in spain. Vet Microbiolo (38) 193-201.

Blanco, J.E., Blanco, M., Blanco, J., Mora, A., Balaguer, L., Cuervo, L., Balsalobre, C. and Munoa, F. (1997): Prevalence and characteristic of enteropathoegenic Escherichia coli eaeA gene in diarrhoeic rabbits. Microbial. Immunol 41:77-82.
Blanco, M.; Schumacher, S.; Tasara, T.; Zweifel, C.; Blanco, J. E.; Dahbi, G.; Blanco, J. and Stephan, R. (2005). Serotypes, intimin variants and other virulence factors of eae-positive Escherichia coli strains isolated from healthy cattle in Switzerland: identification of a new intimin variant gene (eaeๆ2). BioMed Central Microbiology 5, 23.

Cruickshank, R.; Duguiel, J.P.; Marmion, B.P. and Swain, R.H.A. (1975): Medical microbiology. 12th ed. Vol. II Churchill Living stone, Edenburg, London and New York. Des; 5: 895-913.

Cruickshank, R., Duguid, J.P. and Swain, R.H.A.(1982): Medical microbiology, 1070PP.E and S. Livingstone Lom, Edinburgh and London.

Delicato, E. R., DE Brito, B. G., Gaziri, L. C. and VIDOTTO, M. C. (2003): Virulence-associated genes in Escherichia coli isolates from poultry with colibacillosis. Vet Microbiol, 94, 97-103.

Frankel G, Phillips AD, Rosenshine I, Dougan G, Kaper JB, Knutton S (1998):Enteropathogenic and enterohemorrhagic Escherichia coli:more subversive elements. Mol Microbiol, 30:911-921.

Ghosh, S.K. ; Das, A. ; Bujarbaruah, K.M. ; Das, A.; Dhiman, K.R. and Singh, N.P. (2008): effect of breed and season on rabbit production Under 
subtropical climate. World Rabbit Sci. 16: 29 - 33 .

Habeeb, A.A.M.; Marai, I.F.M.; El-Maghawry, A.M. and Gad, A.E. (1997): Growth rabbits as affected by salinity in drinking water under winter and hot summer conditions of Egypt. Egyptian journal of rabbit science, 7(2): 8194.

Hagedorn; Charles; Blanch; Anicet, R.; Harwood, and Valerie J. (2011): Microbial Source Tracking: Methods, Applications, and Case Studies.

Hanchun, Y.; Sheng, C.; David, G.W.; Shaohua, Z.; Patrick, M.; Robert, W. and Jianghong, $M$. (2004): Characterization of Multiple-Antimicrobial-

Resistant Escherichia coli Isolates from Diseased Chickens and Swine in China. Journal of clinical microbiology. 42(8):3483-3489.

Leroy, S. M; Lesage, M. C; Chaslus-Dancla, E. and Lafont, J. P. (1994): Presence of eaeA sequences in pathogenic and nonpathogenic E. coli strains isolated from weaned rabbits. J. Med. Microbiol. 40:90-94.

Maluta, R.P.; Gatti, M.S.; Joazeiro, P.P.; de Paiva, J.B.; Rojas, T.C.; Silveira, F.; Houle, S.; Kobayashi, R.K.; Dozois, C.M. and Dias da Silveira, W. (2014): Avian extraintestinal Escherichia coli exhibits enterotoxigenic-like activity in the in vivo rabbit ligated ileal loop assay. Foodborne Pathog Dis. 11 (6):484-489.

Marches, O.; Nougayrede, J.P.;
Boullier, S.; Mainil, J.; Charlier, G., Raymond, I.; Pohl, P.; Boury, M.; De Rycke, J.; Milon, A. and Oswald, E. (2000): Rate of tiranintimin in the virulence of rabbit enteropathogenic Escherichia coli serotypes 0103: H2 Inf. Immun. 68:217-282.

Mashood, A. R; Uswege, M. and Robertm M. (2009): Day-old infant rabbit model for enterohaemorrhagic Escherichia coli induced diarrhea.veterinarski arhiv 79 (2), 167-177.

Morsy, M.K.; Mohamed, S.Y. and Fathy, H.M (2002):Diarrhea in newly weaned rabbits, (Bacteriological and pathological studies). SCVM, J. (2).

Nataro, J.P. and Kaper, J.B. (1998): Diarrheagenic Escherichia coli. (Clin. Microbiol. Rev., 11: 142-201.

Okerman, L. (1999): Diseases of domestic rabbits. Library of veterinary practice second editionBlackwell science Ltd. U.K.

Peeters, J. E.; Geeroms, R. and Glorieux, B. (1984): Experimental Escherichia coli enteropathy in weanling rabbits: clinical manifestations and pathological findings. (World Rabbit Congress, Rome, vol. 2, Proc. III, p: 273-282). Penteado, A.S.; Ugrinovich, L.A.; Blanco, J.; Blanco, M.; Blanco, J.E.; Mora, A.; Andrade, J.R.S.; Correa, S.S. and Pestana de Castro, A.F. (2002): Serobiotypes and virulence genes of Escherichia coli strains isolated from diarrheic and healthy rabbits in Brazil. 
Veterinary microbiology. 89(1):4151.

Percy, D.H.; Muckle, C.A.; Hampson, R.J. and Brash, M.L. (1993): The enteritis complex in domestic rabbits: a field study . Cand. Vet. J. 34 (2): 95, 98 - 102. Provence, D. L., and Curtiss, R. (1994). Isolation and characterization of a gene involved in hemagglutination by an avian pathogenic Escherichia coli strain. Infect. Immun. 62:1369-1380.

Quinne, P.J.; Carte, M.E.; Markery, B.K. and Carter, G.R. (1994): Clinical Vet. Microbiol. Year book-wolf publishing-Europ limited.

Quinn, P. J.; Markey, B. K.; Carter, M. E.; Donelly, W.J. and Learned, F.C. (2002): Veterinary microbiology and microbial Disease First published-block well ScienceLtd-U.K.

Rahman, M. A.; Samad, M. A.; Rahman, M. B. and Kabir, S.M.L. (2004): Bacteriopathological studies on salmonellosis, colibacillosis and pasteurellosis in natural and experimental infections in chickens. Bangl. J. Vet. Med., 2(1): 1-8.

Saad, A.E. ( 1994): Studies on enteritis in rabbits with special emphasis on bacterial agents $[\mathrm{PhD}$ Thesis]. [microbiology]: Zagazig University, Benha Branch.

Sambrook, J.; Fritscgh, E.F. and Mentiates (1989): Molecular coloning. A laboratory manual. Vol 1., Cold spring Harbor Laboratotry press, New York.

Shahin, A.M.; Lebdah, M.A. and Ali， G.R.M. (2011): Escherichia coli as an etiological agent of mucoid enteropathy in rabbits. Researcher. 3:8!16.

Shehata, A.S.; Sarhan, M.A. and EI-Gendy, K.M.

(1998):

Digestibility, thyroid function and growth performance of New Zealand white rabbits as affected by season of the year and age. Egyptian journal of rabbit science, 8 (2): 141 - 156.

Stakenborg, T.; Vandekerchove, D.; Mariën, J.; Laevens, H.; Imberechts, $H$. and Peeters, J. (2006): Protection of rabbits against Enteropathogenic E. coli (EPEC) using an intemin null mutant. BMC Vet. Res. 2(22) 1186-1746.

WHO (World Health
Organization)

"Escherichia coli O157:H7 Fact Sheets N 125." July 1996.

Wolf, M.W. (1997): Occurrence, distribution and association of $\mathrm{O}$ and $\mathrm{H}$ serogroups, colonization factors antigens and toxins of enterotoxogenic E.coli. Clinical Microbiol. 10(4): 569-584.

Zienab, I. Soliman (2000): Serological O groups and antibiotic sensitivity of $E$. coli strains involved in Enteritis in recently weaned rabbits. J. Egypt. Vet. Med. Ass. 60 (7): 149 - 156. 


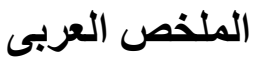

\section{دراسات على الميكروب القولونى المعزول من الارانب حديثة الفطام فى محافظة

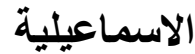

احمد احمد خفاجى- عحم كمال مرسى - دعاء حسين احمد الاسه

استهدفت هذه الدراسة معرفة المزيد عن الميكروب القولونى المسبب للاسهال فى الارانب حديثة

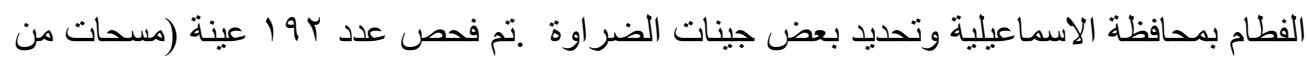

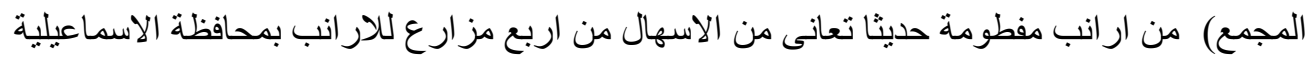

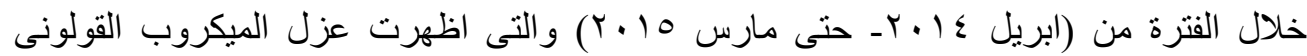

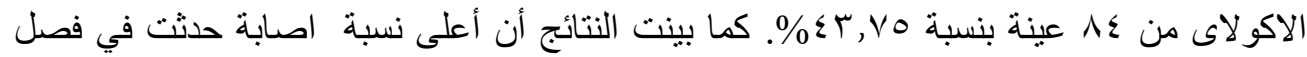

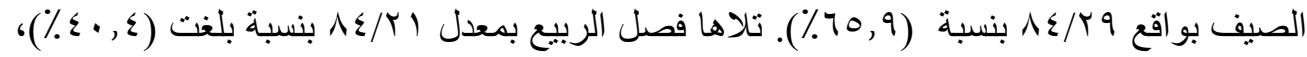

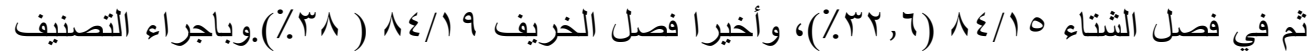

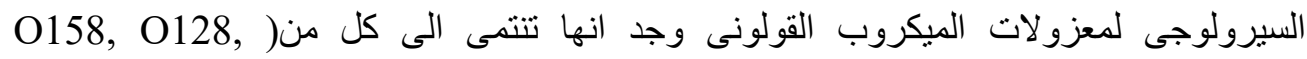

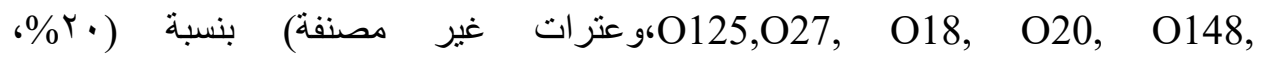

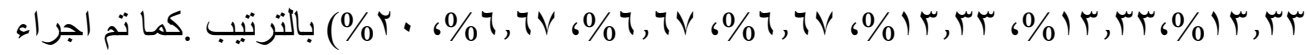

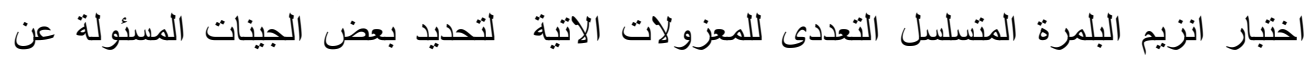

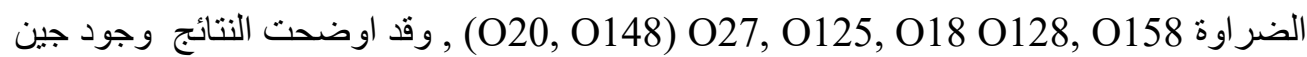
O148 ايضا فى جميع العترات باستثناء عترة (tsh) في جميع العترات كما وجد جين (eaeA) 